\title{
Radical History Then and Now
}

by Caroline Bressey

\section{University College London}

t.bressey@ucl.ac.uk

Almost twenty years ago I began my final-year undergraduate dissertation at Cambridge University. I had chosen to read geography as I felt it would enable me to study the past as well as the present. Throughout my geography degree I maintained a keen interest in history through courses in historical geography, predominately focused on the emergence of modernity and the nineteenth century - including the geographies of the Chartists and Victorian popular culture. When the time came to develop a proposal for my dissertation I was inspired by Dolores Hayden's 1995 book The Power of Place in which through the landscapes of Los Angeles she examines the social and cultural meanings which people invest in places, and how urban landscapes can become a framework for connecting historical stories and public memory in urban life. ${ }^{1}$ I intended my project to focus on the representation of black women in the urban landscapes of London. There are few statues in the suburbs of south-west London where I grew up. But walking through the centre of the city that has always been my home, though I could find black women representing empire in the foundations of memorials to Queen Victoria and Prince Albert, I could not find representations of any 'real' people who were part of the multi-cultural Victorian city.

I had done no black history at school, nor at university, but as I read more about the politics of heritage and memorialization I came to understand how these histories were further marginalized by the location of their biographies within the working-class histories of the city. So to show that black women were absent from spaces of London's heritage I had to prove they were historically present in the city. This research, which took place in the Barnardo's archive, at Barkingside at the eastern end of the Central line, on the site of the charity's former girls' homes, formed the heart of my undergraduate dissertation. Here were the stories of working-class girls, the daughters of migrants and the daughters of Londoners, whose families fell on hard times leaving their parents, often their mothers, with few options of how to care for them, and for many Barnardo's seemed to be a better option than the workhouse. Going into the archives to uncover the lives of black women remains a key focus of my research twenty years later. 
With a subject absent from school and the academy, most of the support I received for my research came from the members of what became known as BASA, the Black and Asian Studies Association. Founded in 1991 the organization existed to promote research into Black lives in Britain and to disseminate findings through its conferences and Newsletter. Primarily based in London, its members included teachers, archivists, independent scholars, and some, but not many, academics. It also lobbied the Conservative Government for recognition of black history in the national curriculum and for libraries and archives to take more seriously their role as custodians of British history in the broadest sense. And slowly there was progress. Individual archivists became members and undertook their own projects, often in their own time, producing small-scale pamphlets and, later, webpages. The introduction of the Heritage Lottery Fund (HLF) brought support for some groups to undertake research projects on local and regional scales.

We can now look back on the 'New Labour' governments of 1997-2010 as a very particular moment in the position of public history and heritage that has been and gone. Though there were many problems with the Blair government, it did oversee a period when 'multi-culturalism' or 'diversity' in our 'Island Story' was acknowledged. The arguments made by community activists over many years, including by BASA members, seemed to be heard in government offices and heritage institutions. The establishment of the Greater London Authority in 2000 and the return of Ken Livingstone to local London government enabled the creation of the Mayor's Commission on African and Asian Heritage, which sat for two years and published Delivering Shared Heritage in 2005. The multi-authored report took evidence from individuals, community groups and heritage organizations. The Commission's findings argued for the importance of embedding representation in heritage, of the need for better workforce diversity, the need for genuine and equitable partnerships between community groups and formal heritage organizations and an education system that included African and Asian histories. ${ }^{2}$

As a commissioner I was not one of those who felt that now the door was open it only had to be pushed all the way free, but I did share the feeling that finally the issues and demands for equality and a re-evaluation of historical research, thought and representation might become core practices - or at least be taken seriously. That was a time when we argued that libraries and archives should stock more black history books and undertake more black history events outside October. Little did we know, and I at 
least did not imagine, that before long we would be defending and apparently losing the argument that libraries and archives were an essential part of civil life and must survive in the public realm.

Under the Conservative-led coalition government, hard-won arguments about diversity were shown to be vulnerable and seemingly easily contested. The current tenor of the debates around us now can be seen as beginning when Michael Gove was made Education Secretary in May 2010. He introduced his announcement of a curriculum review in 2011 with a lamentation that the national history curriculum in schools failed to include Churchill, Queen Elizabeth, Gladstone, Disraeli, Florence Nightingale and Horatio Nelson. ${ }^{3}$ As Jonathan Petre reported in the Daily Mail, with the proposed new curriculum pupils would be required to 'study these traditional historic figures - and not social reformers such as Jamaican-born nurse Mary Seacole and former black slave Olaudah Equiano', characters who were introduced into the curriculum in 2007, during the New Labour Government. Petre expected that the proposals were 'certain to anger equality activists who believe history lessons are too skewed towards white British men'. 4

As many will remember, Gove's intentions for school history (and other subjects) did indeed generate tense debate on the role of politics in the teaching of history. ${ }^{5}$ When an outline of the new proposals was published in February 2013 Martin Spafford, a London-based history schoolteacher and member of BASA, observed that bar 'two Tudor queens, women only enter history in the mid nineteenth century'. And with regard to black history:

According to Gove, however, there were no British people of African or Asian origin until after the Second World War. They are invisible in the primary curriculum and first appear in secondary schools when enslaved. This matters because a 'whitewashed' story of these islands can propagate the lie that the narrative belongs only to some of us while others are excluded. In uncertain times these are dangerous myths for young minds: thereby lies disaster, as we understand so well from recent history. Without 
understanding our continual and everchanging diversity we cannot know Britain. $^{6}$

That the draft national curriculum published in February 2013 was an improvement on the initial plans published by the Daily Mail in December 2012 says much - Mary Seacole remained, kept on in a section on the changing role of women, to be taught within an understanding of 'Britain's social and cultural development during the Victorian era'. ${ }^{7}$ The debates around the proposals illustrated how easy it is for arguments thought to have become core to historical practice, such as the centrality of women's history to historical work, to be questioned, and for the key points they sought to establish to remain undervalued and contested. ${ }^{8}$ Stuart Hall argued that 'Little Englander nationalism' would hardly be able to survive if people really understood the networks of empire, of whose sugar flowed through English blood and rotted English teeth. ${ }^{9}$ Focusing minds on the dates of kings and a couple of queens is one way to redirect people's understandings of their history. However, Gove's decision to change the examinations taken by fifteen and sixteen-year-olds presented an opportunity to challenge the conservative intentions of his policies. A number of BASA members were involved in the planning of a new GCSE being developed by an exam board, that covers significant periods of immigration to Britain since the Roman period and became available to be taught in schools from September 2016. ${ }^{10}$ But Gove's vision of Britain and that of other 'Little Englanders' showed itself still powerfully strong during the debate before the referendum on Britain's position within the European Union. Since the result in June 2016 reports of racial attacks in England have increased. Once again questioning who 'belongs in Britain' has been made a political cudgel with which to divide, blame and batter, and once again the need to illustrate and draw attention to the history of black and many other kinds of Britons is urgent. Though we are not in exactly the same position as we were twenty years ago. Delivering Shared Heritage was published and a number of museums, galleries and archives have sought to diversify their collections since. Numerous school children will have studied slavery and abolition, though these are tricky subjects as on the one hand a history of abolition can be taught without including any black history and it is problematic if the only time black people appear in school history is as nameless enslaved people who are often not even placed in Britain. Some school children will have learned about the abolition activism of Olaudah Equiano and the work of Mary Seacole on the battlefields of the Crimea, 
and though there are not many more black academic historians, there have been a few more PhDs in the subject. ${ }^{11}$

There have also been changes to the urban landscape - in the same month as the British EU referendum a statue of Mary Seacole was unveiled in the grounds of St Thomas's hospital, London. But though she is hardly a radical figure, the opposition to it, (as from members of the Florence Nightingale Society who protested that Seacole's fame is the result of a 'campaign of misinformation'), illustrates the resentment of and resistance to finding space for black history in Britain. ${ }^{12}$ Black radical histories - of the political activists, of working class men and women, of queer black histories - remain incredibly marginalized.

The up and running History Matters campaign came out of a conference held in April 2015 that sought to understand why there are so few school and university history students and teachers of African and Afro-Caribbean descent. ${ }^{13}$ It was felt at the conference that the British history taught in schools remains an overwhelmingly white one - as one young woman recalls in the film which History Matters made, the history she learned was the history of white middle-class men and how they became powerful; such black history as there was, was the story of black America. ${ }^{14}$

But, despite the barriers, as the History Matters campaign illustrates, people, perhaps especially young people, are deeply interested in history; they enjoy it, can be inspired by it and recognize that it is important to them and the communities in which they live. In the coming years it seems likely that they will need it, so with all the cuts and political manoeuvrings to come, we must consider how to ensure they can continue to access the tools of history making. How can collections, archives and libraries be maintained so as to allow black history - all diverse histories - to go on being researched, written about, debated and enjoyed? That remains as vital a question for the public history movement as ever.

\section{NOTES AND REFERENCES}

This essay is based on a talk given at the conference Radical Histories / Histories of Radicalism (London, June 2016), which in part drew on the chapter 'Conversations with Caroline', in How Empire Shaped Us, ed. Antoinette Burton and Dane Kennedy, London, 2016, pp. 183-93. 
1 Dolores Hayden, The Power of Place: Urban Landscapes as Public History Cambridge MA, MIT Press, 1995.

2 I was one of twenty commissioners who sat from 2003 to 2005. MCAAH, Delivering Shared Heritage, Greater London Authority, 2005. Aspects of the research findings were developed in MCAAH, Embedding Shared Heritage: the Heritage Diversity Force Report, Greater London Authority, 2009.

3 Michael Gove, 'National curriculum review: children failed by Labour's education reforms', Daily Telegraph, 20 Jan. 2011

(http://www.telegraph.co.uk/education/educationnews/8269906/National-curriculumreview-children-failed-by-Labours-education-reforms-says-Gove.html).

4 Jonathan Petre, 'Gove faces war with equality activists as he axes Labour's PC curriculum that dropped greatest figures from history lessons', Mail Online, 29 Dec. 2012.

5 I discuss this in Caroline Bressey, 'Geographies of Belonging: White Women and Black History', Women's History Review 22: 4, 2013, pp. 541-58.

6 Martin Spafford, 'How Michael Gove is dumbing down the history curriculum', 1 March 2013 (http://guest.schoolshistoryproject.co.uk/2013/03/01/howmichael-gove-is-dumbing-down-the-history-curriculum/).

7 Historical Association, 'The New History Curriculum - Read it here', 8 Feb. 2013 (http://history.org.uk/ha-news/news/1715).

8 Cathy Newman, 'Will Gove's 'posh white blokes' history curriculum ignore women?'. Daily Telegraph, 9 Jan. 2013

(http://www.telegraph.co.uk/women/womens-life/9790633/Will-Goves-posh-whiteblokes-history-curriculum-ignore-women.html).

9 Tim Adams, 'The Interview: Cultural Hallmark', Observer, 23 Sept. 2007 (http://www.theguardian.com/society/2007/sep/23/communities.politicsphilosophyan dsociety).

10 OCR Exam Board: http://www.ocr.org.uk/news/view/ocrs-new-historygcses-to-explore-migration-into-britain-down-the-ages/.

11 For examples of discussion on why there are so few black academics see Deborah Gabriel, 'Race equality in academia: time to establish black studies in the UK?', Guardian, Higher Education Network Blog, 25 July 2013; Daniel Boffey, 'Only three black applicants win places to train as history teachers', Guardian, 22 March 2014. 
12 For these debates see Kashmira Gander, 'Mary Seacole statue: Why Florence Nightingale fans are angry the Crimean War nurse is being commemorated', Independent, 24 June 2016; and Nightingale Society, Seacole statue letters (http://nightingalesociety.com/correspondence/statue/seacole-statue-archived/)

13 The film made by History Matters is available to view on Vimeo:

https://vimeo.com/139440543. History Matters and the University of Chichester, 2015 14 The comments are made in the film by Nura Hassan, an A-level student. 